\title{
ANNA PRZYTOMSKA
}

Uniwersytet im. Adama Mickiewicza

\section{Historia tubylcza. Szamani Kiczua i mitopraktyka}

\author{
Przyszłość jest z tyłu, dlatego dzieci nosimy na plecach \\ K.A. Layme
}

W Andach ekwadorskich górscy Indianie Kiczua nazywają swoich szamanów yachak (kicz. ten, który wie). Yachak to pośrednik pomiędzy światem ludzi i nie-ludzi (bóstwami, osobową naturą, przodkami), pełniący funkcję medyczną oraz rytualną. Wiedza przekazywana z pokolenia na pokolenie w tradycji ustnej oraz dar są podstawą ich statusu i prestiżu w lokalnych wspólnotach (hiszp. comunidades). Pełniąc szereg funkcji społecznych, przyczyniają się bowiem do podtrzymywania ciągłości kulturowej, tożsamości i odrębności grupy. Podstawowym zadaniem yachak jest utrzymywanie społeczności w zdrowiu, diagnozowanie i leczenie chorób. Jako jedyni członkowie grupy sprawują funkcję rytualną. Kontaktują się z przodkami i bytami nie-ludzkimi ${ }^{1} \mathrm{w}$ celu utrzymania ciągłości i harmonii pomiędzy światem ludzi i nie-ludzi. Nauczając o wierzeniach, historii i normach, kształtują społeczny światopogląd. Są przewodnikami oraz nauczycielami dla swoich wspólnot. Ponadto część z nich orientuje się i aktywnie uczestniczy $\mathrm{w}$ relacjach interetnicznych związanych z polityką, edukacją, w tym walką o prawa Indian.

Tłem dla współczesnych praktyk yachak jest nowa sytuacja polityczna w Ekwadorze ${ }^{2}$. Samoaktywizacja Indian oraz nadanie im szeregu nowych praw przez państwo wywołały stopniowe transformacje w relacjach pomiędzy społeczeństwem metyskim a tubylczym. Współcześnie Indianie ekwadorscy postrzegani są jako aktywni i świadomi gracze, którzy inteligentnie wykorzystują nie-

\footnotetext{
${ }^{1}$ Tak zwane osoby nie-ludzkie, czyli byty osobowe, zamieszkujące np. różne elementy środowiska przyrodniczego. Jednym z przykładów jest apu - duch-opiekun, zamieszkujący szczyty górskie lub wulkany.

${ }^{2}$ Chodzi tu o „indiańskie odrodzenie" czy "tubylczy aktywizm”, będące wynikiem rozpowszechnienia się idei demokracji w Ameryce Płd. (w tym praw i wolności człowieka) za sprawą działań organizacji pozarządowych (np. IWGiA, Survival International), ruchu indygenistycznego, inicjatyw oddolnych (strajki, blokady dróg, marsze), a także wzrostu edukacji i w konsekwencji powstania elit tubylczych (organizacje indiańskie) (Coronado 2009: 163-169; Posern-Zieliński 2005: 38-39).
} 
dawno uzyskane prawa i przywileje. Nowa sytuacja społeczno-polityczna dała Indianom możliwość otwartego mówienia o sobie oraz definiowania siebie.

Podczas badań etnograficznych nad praktykami szamanistycznymi u Kiczua z Andów ekwadorskich ${ }^{3}$ moją uwagę zwróciły sposoby postrzegania i reprodukcji historii przez yachak. Strategie i mechanizmy prowadzenia przez nich narracji historycznej, które są przedmiotem analizy tego tekstu, nazywam mitopraktyką, gdyż ich działania opierają się gównie na reinterpretacji dawnych mitów przy jednoczesnym przywracaniu zapomnianych bądź porzuconych elementów własnej kultury oraz inkorporowaniu nowych. Poprzez analizę mitopraktyki staram się pokazać, jak szamani z Andów ekwadorskich rozumieją historię, a w konsekwencji w jaki sposób budują swą współczesną podmiotowość i tożsamość w wieloetnicznym społeczeństwie Ekwadoru. Bardzo ważnym elementem tego procesu przebudowy jest właśnie historia. Yachak, oprócz pełnienia swych tradycyjnych funkcji, uzyskali szansę bycia (współ)twórcami historii - podmiotem działania historycznego w obrębie rodzimych wspólnot, lecz także $\mathrm{w}$ przestrzeni ponadlokalnej. Taka sytuacja rodzi pytanie - dlaczego właśnie oni i jaka część z nich uzyskuje możliwość tworzenia historii? Po pierwsze, niezbędnym fundamentem jest posiadana przez nich wiedza i prestiż. Po drugie, z moich obserwacji wynika, że wszyscy aktywni szamani żyją i działają w przestrzeni interetnicznej, tj. służą wspólnotom lokalnym przy jednoczesnym utrzymywaniu stałych kontaktów ze społeczeństwem metyskim. Punkt tej styczności staje się dla nich optymalnym miejscem, z którego czerpią korzyści społeczne, ekonomiczne i polityczne. Ponadto są to osoby, które często zostały wykształcone w systemie edukacji społeczeństwa większościowego, mocno aspirują do tego świata, przy jednoczesnym dezawuowaniu lub negacji zachodnich wartości oraz podkreślaniu wyższości kultury przodków, a w konsekwencji głoszeniu potrzeby powrotu do „korzeni”.

\section{Wprowadzenie. Historia tubylcza}

Od czasów konkwisty narracja historyczna o Nowym Świecie prowadzona była głównie przez Europejczyków (misjonarzy, kronikarzy i historyków) i ignorowała głosy Indian. Opowieści o ludziach tak odmiennych kulturowo konstru-

\footnotetext{
${ }^{3}$ Badania terenowe, które są podstawą tego tekstu, prowadziłam w Ekwadorze od czerwca do listopada 2010 r. oraz od sierpnia do listopada 2012 r. u Indian Kiczua z prowincji Imbabura (Kiczua-Otavalos) i Chimborazo (Kiczua-Puruhá). Tym samym należy zaznaczyć, iż omawiane przeze mnie mechanizmy nie dotyczą wszystkich Kiczua. Ponadto w ramach tych dwóch prowincji nie wszyscy znani mi yachak reprezentują przedstawianą tu reinterpretację historii i nie jest dla nich tożsama. Niżej opisane działania i idee znacznie silniej zakorzenione są w prowincji Chimborazo i tutaj szukałabym ich źródła. Wprawdzie ze względu na dużą mobilność yachak pojawiają się one w różnych częściach Ekwadoru, spotykają się jednak z różnym, większym lub mniejszym, entuzjazmem i w odmienny sposób są reinterpretowane oraz inkorporowane.
} 
owane były za pomocą kategorii europejskich, nieprzystających do tubylczych koncepcji i struktur myślowych. Grupy rdzenne postrzegane były jako ludy bez historii, tzw. zimne społeczeństwa (Lévi-Strauss 1969: 233-236) - proste, trwające poza historią i czasem ${ }^{4}$. Tubylcy byli przedmiotami, a nie podmiotami historii (Young 2012: 167). Dopiero w latach 70. i 80. XX w. ${ }^{5}$ historycy dosłyszeli stłumiony głos tubylca. Rozkwitł wówczas nowy projekt historyczny - etnohistoria (także: historia antropologiczna, mikrohistoria). Subdyscyplina ta polega na reinterpretacji źródeł historycznych przy wykorzystaniu perspektywy antropologicznej ${ }^{6} \mathrm{w}$ celu zrekonstruowania historii danej grupy. Rozwój etnohistorii związany był z postępującym po II wojnie światowej procesem dekolonizacji, demokratyzacją i skierowaniem zainteresowań badawczych na historię i kulturę grup dotąd "wykluczonych". Wiązało się to także z krytyką europocentryzmu (",odeuropeizowanie" historii) oraz rozkwitem idei równości i wielokulturowości (Domańska 2010: 200-201). W kontekście pozaeuropejskim jednym z głównych elementów tego projektu był proces odzyskiwania głosu tubylca oparty na tzw. historii ludowej (ang. folk history, także: historia oddolna, historia oralna), która stała się domeną nie tylko historyków, ale także antropologów. Badania te przyczyniły się do poznania alternatywnych (innych niż ,zachod-

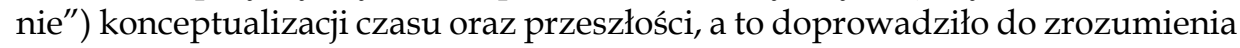
odmiennych interpretacji współczesnych wydarzeń (Posern-Zieliński 1987: 93). Zauważono wkrótce, że "różne porządki kulturowe mają swe własne tryby historycznego działania, świadomości i określenia - własną praktykę historyczną" (Sahlins 2003: 118) .

\footnotetext{
${ }^{4}$ W odróżnieniu od społeczeństw "gorących", które czynią historię i zmianę podstawą swego rozwoju. Historia rozumiana jest tutaj w duchu heglowskim, jako dzieje postępu, droga „od czasów ciemności ku światłu”. Leela Gandhi (2008: 152) pisze, że w konsekwencji takiego sposobu myślenia broniono często „zachodniej ekspansji imperialistycznej jako przedsięwzięcia pedagogicznego, mającego wprowadzić nierozwinięte obszary świata we wzniosły stan historii".

${ }^{5}$ Korzeni etnohistorii część badaczy doszukuje się już w XIX-wiecznej Europie, np. w pracach J. Micheleta, T. Carlyle'a i T. Macaulaya. Podobne historyczne podejście rozwijali annaliści pierwszego pokolenia (M. Bloch i L. Febvre). Prace te dotyczyły jednakże tylko społeczeństwa europejskiego.

${ }^{6}$ Na gruncie badań obszaru Ameryki Łacińskiej należy wskazać dwie pionierskie prace - La visión de los vencidos z 1959 r. autorstwa historyka i antropologa M. León-Portillii, dotycząca wizji konkwisty Indian Nahua, oraz książka La Vision des Vaincus - Les Indiens du Pérou devant la Conquête Espagnole (1530-1570) z 1971 r. autorstwa Nathana Wachtela, poświęcona ludowej wizji historii Andów (Salomon 1999: 51-52).

${ }^{7}$ Niemniej zadaniem antropologa badającego przeszłość nie jest poszukiwanie „słusznej historiografii", lecz odkrywanie znaczenia przeszłości, jakie nadają jej ludzie w biegu swojego życia. Ponadto folk history to nie tyle historia opowiadana przez tubylców, ile rekonstrukcja narracji o przeszłości danej grupy. Mimo iż są to narracje tubylcze, zbierane są i reinterpretowane przez badaczy pochodzących z innych kręgów kulturowych. Konstruowane opowieści nie są więc odbiciem "czystej” tubylczej historiografii, lecz tekstem niepełnym, fragmentarycznym, a przede wszystkim obarczonym nieuniknionym, kulturowym „piętnem” badacza.
} 
W ciągu ostatnich dwóch dekad $\mathrm{w}$ obrębie nauk społecznych, oprócz dostrzeżenia alternatywnych narracji o przeszłości, zmianie uległo także postrzeganie samej historii - jako dyscypliny naukowej. Sprzyjała temu pogłębiona analiza modeli narracji historycznych. Akcent przeniesiono z badań długich strukturalnych interwałów czasowych na rzecz narracji teraźniejszych, a analizę systemów pokrewieństwa, polityki, ekonomii, religii przesunięto na sposoby działania człowieka, relacje władzy i podporządkowania, sprawczość czy tożsamość. Współcześnie historia rozumiana jest jako konstrukt kulturowy, tj. jej rozumienie zależy od kontekstu kulturowego (np. kategorii czasu i zmiany). Jest także strukturą narracyjną, konstruowaną zawsze przez określony podmiot dla konkretnych odbiorców - to, o czym pamiętamy, może być wybiórcze, fragmentaryczne, a czasami kontrolowane. Moje rozumienie historii bliskie jest koncepcjom amerykańskiego antropologa Marshalla Sahlinsa (2006), którego prace od drugiej połowy lat 70. XX w. skupiają się na związkach antropologii z historią oraz na sposobach rozumienia i konstruowania historii przez różne kultury. Jego główna myśl koncentruje się na krytyce koncepcji obecnych w nauce zachodniej, które prowadzą do rozróżnienia przeszłości, teraźniejszości i przyszłości oraz struktury i zdarzenia. W wizji Sahlinsa następuje sprzężenie zwrotne pomiędzy historią a kulturą. Historia jest zorganizowana przez kulturowy schemat, który należy czytać diachronicznie. Nie jest jednak dany raz na zawsze, gdyż znaczenia są przedmiotem przewartościowania w trakcie ich odgrywania8.

Historia wiąże się z pamięcią, a ta w kontekście dziejów Nowego Świata jest pomostem pomiędzy okresem kolonialnym a teraźniejszością. Pamiętanie „,nigdy nie jest cichym aktem introspekcji czy retrospekcji; jest bolesnym przypominaniem, montowaniem rozczłonkowanej przeszłości po to, by pojąć sens traumy teraźniejszości" (Bhabha 1994: 63). Historia, jako opowieść o ludzkim życiu, staje się tym samym opowieścią o zmianie. Dawne teorie antropologiczne przedstawiały zmianę kulturową Indian jako proces utraty „tubylczości” oraz negatywnie postrzeganą transformację dotąd niezmiennej i nieskażonej kultury indiańskiej. Najnowsze prace antropologiczne oraz etnohistoryczne dotyczące sposobów konstruowania przeszłości przez Indian Ameryki Płd. oraz historii ich relacji z nie-Indianami mówią o mimetycznym przywłaszczaniu elementów kultury Europejczyków przez Indian i tylko pozornej dezintegracji czy akul-

\footnotetext{
${ }^{8}$ Jeszcze w latach 90. XX w. dominujący dyskurs konstruujący obraz zmian sytuacji ludów tubylczych kreował teraźniejszość jako dezorganizację, przeszłość jako czas porządku, a przyszłość jako asymilację. W konsekwencji zwrotów paradygmatycznych w humanistyce, dekolonizacji oraz tzw. odrodzenia tubylczego współczesna opowieść o Indianach zmierza w innym kierunku. Teraźniejszość postrzegana jest jako opór i walka z dominacją, przeszłość jawi się jako ucisk i przemoc, a przyszłość jako etniczne odrodzenie. Edward M. Bruner (2011: 150), który analizuje podobne procesy w kontekście Indian północnoamerykańskich, twierdzi, że przejście pomiędzy jedną a drugą opowieścią jest właściwie jej zerwaniem. W ciągu ostatnich kilkunastu lat badacze położyli większy nacisk na dekonstruowanie sposobów, w jakie społeczeństwa kolonialne „tworzone” były przez historyczne i etnograficzne dokumenty, oraz na wpływ władz kolonialnych, które manipulowały wiedzą wyrosłą na ich podstawie (Axel 2002: 1-33).
} 
turacji, która w rzeczywistości stanowi formę strategii adaptacyjnych. Celem pozornego (świadomego czy też nie) procesu upodabniania jest podtrzymywanie własnych idei i praktyk. Zmiany dotyczą zazwyczaj treści kulturowych, a nie głębokich przebudowujących struktur, które są rdzeniem każdej z kultur (sposobów myślenia czy ontologii). Tacy badacze jak (wspomniany już) Marshal Sahlins czy Peter Gow $(1997,2001)$ w swych studiach etnohistorycznych zmianę rozumieją jako mechanizm transformacji konieczny do zachowania ciągłości kulturowej danej społeczności, zaś antropologię traktują jako narzędzie do (często) trudnych prób wykazywania synchronicznej kontynuacji pomiędzy przeszłością a teraźniejszością. Próbują przybliżyć relację pomiędzy zanikiem a reprodukcją (zmianą a strukturalną ciągłością). Innymi słowy, fundamentem dla bycia i działania człowieka jest dynamika, w której transformacja jest konstytutywną częścią trwałości (Fausto, Heckenberger 2007: 6).

Innym, ważnym aspektem etnohistorii jest ukryte napięcie pomiędzy respektowaniem historii tubylczej (wymagającej epistemologicznego uwzględnienia „innej” wizji świata) a uznaniem tubylczych podmiotów (szamani, lokalni przywódcy i politycy), którzy tworzą i prowadzą tę alternatywną narrację (Salomon 1999: 51). Owi narratorzy nie są odcięci od świata zewnętrznego, znajdują się w przestrzeni przecięcia dwóch światów - indiańskiego i nie-indiańskiego. W związku z tym teksty, które tworzą, są wynikiem tej specyficznej sytuacji kontaktu i wzajemnych interakcji. Mając to na uwadze, nie można traktować tych dwóch wizji w sposób rozdzielny. Przywołać tu mogę amerykańską filozofkę i etnohistoryczkę Erin O'Connor (2003), która postuluje analizę zjawisk historycznych poprzez połączenie tubylczych ujęć przeszłości z konwencjonalnymi badaniami historycznymi. O'Connor utrzymuje, że projekty te (narodowy i etnohistoryczny) nie są tylko paralelnymi opowieściami o życiu danej grupy, które można porównać, lecz historiami nierozerwalnie związanymi. Podejście to nie ogranicza się jedynie do „włączenia Indian” do narodowej narracji historycznej. Wskazuje ono na związek przyczynowo-skutkowy pomiędzy obiema perspektywami oraz na ich punkty przecięcia. Kluczowe jest tu poznanie i analiza owych połączeń dla zrozumienia mikro- i makrohistorii. Taką samą perspektywę zakładają badacze Amazonii, którzy postulują potrzebę pogodzenia analizy tubylczych kosmologii z sytuacją społeczno-historycznego kontaktu (Albert, Ramos 2002) ${ }^{9}$.

\footnotetext{
${ }^{9}$ Etnograficzne monografie coraz częściej włączają diachroniczną perspektywę do "tradycyjnych" historii, tworząc lokalne mikrohistorie oczekujące na nowe regionalne syntezy. Współczesne antropologiczne teksty traktujące o przeszłości danej grupy są przede wszystkim narracjami o zmianie. Pokazują nam, że historia jest zakorzeniona w ludzkim działaniu zdolnym do transformowania świata społecznego, a przeszłość, teraźniejszość i przyszłość łączą się w homogeniczną całość poprzez to osobowe działanie. Konstatacje amazonistów ujawniają jednak bardzo istotne problemy natury ontologicznej i epistemologicznej. Jak mówić o historii i działaniu w historii, jeśli sprawczość w świecie Indian przypisywana jest także osobom nie-ludzkim? I jak połączyć tubylcze kategorie działania i zmiany z tymi faktami? Zdaniem C. Fausto i M. Heckenbergera zachodni termin „działanie historyczne” odpowiada tubylczemu rozumieniu „szamańskiego działania” (Fausto, Heckenberger 2007: 16-18).
} 
Badania etnohistoryczne pokazują, że w czasach kolonialnych szamani zarówno z obszaru andyjskiego, jak i Amazonii ${ }^{10}$ (Oberem 1971) nie byli wyłącznie niemymi ofiarami biernie poddającymi się procesowi ewangelizacji i akulturacji. Od samego początku okresu kolonialnego stawiali opór, organizowali powstania oraz rebelie przeciwko najeźdźcom. Ponadto uczestniczyli i współtworzyli ówczesny kreolsko-indiański świat. Studia nad XVIII-wiecznymi procesami czarowników w Królewskiej Audiencji Quito (1563-1822) prowadzone przez amerykańskiego etnohistoryka Franka Salomona (1983) pokazują, że jednym z głównych czynników działań antykolonialnych była "magiczna agresja” szamanów zwana potocznie czarownictwem. Wynika z nich, że szamanizm był początkowo mechanizmem oporu, który regulował relacje dominacji i podporządkowania narzucone przez administrację kolonialną. Mechanizmy te były najbardziej widoczne na peryferiach - tam, gdzie kontrola administracji była mało skuteczna i niewystarczająco silna, by efektywnie przeciwstawić się władzy reprezentowanej m.in. przez szamanów oraz w rzeczywisty sposób wpłynąć na polityczne zależności wewnątrz wspólnot indiańskich ${ }^{11}$. „Czary” były także mechanizmem adaptacji do nowej sytuacji kolonialnej ${ }^{12}$. Indiańscy szamani przystosowywali się do kolonialnej sytuacji w różnorodny sposób - np. blokowano prawne systemy władzy przez tworzenie zbuntowanych grup. Niezrozumienie odmiennych kulturowo praktyk oraz brak mechanizmów obronnych lub prewencyjnych przed "magiczną" agresją oznaczało bezsilność administracji, a czasami także jej uzależnienie od szamanów. Salomon opisuje przypadki, w których interetniczna agresja szamanów wykorzystywana była przez samych kolonizatorów w kontaktach ze społecznością tubylczą oraz $\mathrm{w}$ wewnątrzkolonialnych rozgrywkach politycznych. Spowodowane to było m.in. brakiem alternatywy lub chęcią skorzystania z podstępnych (relatywnie łatwo dostępnych) form obrony lub ataku ${ }^{13}$. Sytuacja ta

\footnotetext{
${ }^{10}$ Oberem opisuje antykolonialną konspirację szamanów z grupy Quijo z obszaru selva alta Ekwadoru z początku lat 60. XVI w., która była odpowiedzią na akcje osadnicze Hiszpanów. Indianie szybko stali się przedmiotem eksploatacji i depopulacji za sprawą encomiendas, repartimiento, przymusu płacenia trybutu, upadku kacykatu oraz lokalnego handlu oraz epidemii. Ta dramatyczna sytuacja doprowadziła do utworzenia lokalnej konspiracji złożonej głównie z szamanów (pende), ale także ich sprzymierzeńców - szamanów z Andów i innych cześci Amazonii. Jednakże, mimo początkowej przewagi, powstanie upadło - nie udało im się zdobyć Baeza (głównej osady), a informacje o spisku w Quito szybko dotarły do Hiszpanów (Oberem 1971).

${ }_{11}$ Andyjskie społeczeństwa tubylcze postrzegane były początkowo przez Hiszpanów jako nieposiadające przywództwa (ang. leaderless) (z wyjątkiem grup, do których oddelegowano kolonialnych przywódców) oraz nieopanowane (ang. ungovernable). Takie założenia utrudniały jedynie zarządzanie indiańskimi grupami.

${ }_{12}$ Badacze szamanizmu w Amazonii twierdzą, że w społeczeństwach, gdzie nie docierało państwo oraz gdzie nie występował system dziedzicznego wodzostwa, wewnętrzne konflikty szamańskie polegały na stałych, nieprzerwanych aktach magicznej agresji i leczenia. Ciągła rywalizacja walczących przeciwko sobie szamanów stanowiła w rzeczywistości wewnętrzną formę ustalania wodzostwa (Whitten 1976: 141-163; Harner 1984).

${ }^{13}$ Opisywany przez Salomona (1983: 422-425) przypadek z 1703 r., który miał miejsce w wiosce Intag (współcześnie - kanton Otavalo, prowincja Imbabura), demonstruje sytuację, w któ-
} 
doprowadziła do włączenia siły magiczno-politycznej indiańskich szamanów do systemu kolonialnego. "Czary” były więc narzędziem nawiązywania sprawczych relacji - kontroli i zdobywania władzy, a także zwierciadłem „osobliwej słabości” władzy kolonialnej (Salomon 1983: 425).

Badania terenowe prowadzone przez Stevena Webstera (1974-1976: 143-156) w latach 70. XX w. wśród andyjskich Indian Kiczua dowodzą, że szamańska agresja wciąż jest czynnikiem warunkującym przywództwo grupy (tylko silni szamani, o dużej mocy i prestiżu są przywódcami wspólnot) oraz stanowi istotny element współczesnych stosunków wewnątrzindiańskich i relacji metysko-indiańskich, co potwierdzają także aktualne badania (w druku, Przytomska 2014a).

\section{Czas i zmiana w kosmowizji Kiczua}

By przejść do analizy tubylczego rozumienia historii, konieczne jest odniesienie do kategorii czasu i zmiany. W kosmowizji Kiczua czas i przestrzeń łączą się w jedną koncepcję, w kiczua określaną jako pacha. Przestrzeń wyznaczana jest przez czas i odwrotnie. W kategoriach przestrzennych pacha podzielona jest na Janan Pacha, Kay Pacha, Uku Pacha. Janan Pacha to przestrzeń górna, zamieszkana przez ciała niebieskie (gwiazdy, słońce, księżyc), tęczę, ptaki, dlatego też kojarzona jest z ciepłem, światłem, jasnością. Rozumiana jest także jako przestrzeń wypełniona Jatun Samay (Wielkie Tchnienie). Kay pacha (kicz. ten świat), zwany także Pachamama (kicz. Matka Ziemia), to przestrzeń zamieszkana przez istoty ziemskie - ludzi, góry, jeziora, rzeki, rośliny i zwierzęta i inne osobowe byty. Według Kiczua kay pacha oznacza wszystko to, czego człowiek doświadcza za pomocą zmysłów. Uku Pacha (kicz. świat dolny) to świat wewnętrzny, przestrzeń zamieszkana przez mallquis (kicz. przodków). Światy te nie są rozdzielone, tworzą spójną i uzupełniającą się całość, będącą w stałej relacji. Drugie założenie pojęcia pacha odnosi się do biegu czasu. Czas w kulturach „zachodnich" jest linearny, co oznacza, że biegnie z punktu początkowego do finalnego, a więc ma swój początek i koniec. U Kiczua (i innych tubylczych grup andyjskich) czas przybiera formę spiralną i charakteryzowany jest jako muyuy, czyli ",ten, który powraca”, ,"ten, który krąży". Muyuy wywodzi swój źródłosłów od słowa muyu, które w kiczua ma dwa znaczenia: 1) kula, piłka, okrągły przedmiot; 2) nasienie, bulwa przeznaczone do sadzenia, rozsadzania (rozmnażania) (Cordero 2006: 73). W kosmowizji Kiczua czas jest zatem powtarzalny. Można to porównać do zjawisk, takich jak nastawanie dnia i nocy czy cykliczne zmiany pór roku. Kategorie czasowe nie są ani przeszłe, ani przyszłe. Oznacza to, że kosmowizja Kiczua wyklucza czasy względne - przeszłość, teraźniejszość, przyszłość. Innymi słowy, przeszłość i przyszłość zawarte są w teraźniejszości. W konsekwencji takiego myślenia historia Kiczua nie jest kategorią przeszłą, a raczej czasem, który powróci, by stać

rej przedstawiciele władzy kolonialnej korzystali z usług szamanów do rozwiązywania swoich wewnętrznych konfliktów. 
się „teraźniejszością”. Nie oznacza to jednak, że Kiczua nie zauważają biegu czasu. Posługują się dwiema kategoriami czasowymi, wyrażanymi w formie przysłówków: ñaupa (kicz. wcześniej) oraz quipa (kicz. później). Przykład: micush quipa - po jedzeniu, kay chishi quipa - po tym wieczorze. Ñaupa odnosi się zarówno do czasu, jak i miejsca - oznacza „wcześniej” oraz „przed”, „z przodu”. Ñaupachina - oznacza wyprzedzić i, tak jak w języku polskim, ma dwa znaczenia: wyprzedzić jako czynność czasowa (np. wyprzedzić spłatę czegoś) bądź wyprzedzić w odniesieniu do miejsca (wyprzedzić np. samochód). Czas ma zatem porządek jakościowy, związany jest bowiem z konkretnym wydarzeniem lub działaniem człowieka ${ }^{14}$. Porządek czasowy jest silnie zaznaczony w życiu Kiczua. Działanie i życie człowieka związane jest bowiem z cyklem Pachamama, która wyznacza czas właściwy dla każdego ludzkiego działania, np. czas siewu, okopywania czy zbiorów. Jeśli określona czynność będzie wykonana niezgodnie ze swym przeznaczeniem miejsca oraz czasu, nie przyniesie odpowiedniego efektu. Dotyczy to świąt, rytuałów oraz czynności dnia codziennego ${ }^{15}$.

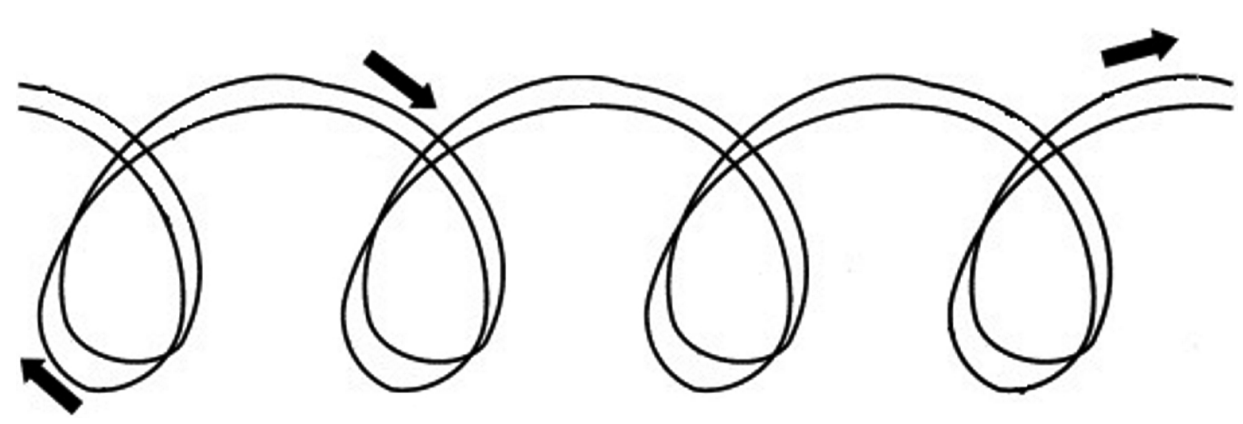

Rys. 1. Struktura powtórzeniowa. Bieg czasu według koncepcji Kiczua

W konsekwencji takiej koncepcji czasu zmiana rozumiana jest jako forma powtórzenia oraz powrotu. Jednakże Kiczua podkreślają, że to, co powróci, nie będzie wiernym odtworzeniem tego, co już się wydarzyło. Czas i przestrzeń nie są więc stałe. W nich zawarty jest proces transformacji opartej na działaniu człowieka. Mówiąc prościej, życie Kiczua to stała transformacja (działanie), która biegnie po spiralnej osi czasu i przestrzeni i opiera się na sprzężonych

${ }^{14}$ Dla Indian Kiczua przyszłość nie jest czymś, co przychodzi lub nadchodzi z przodu, lub czymś oczekującym na urzeczywistnienie. Przeszłość nie jest zaś czasem, który odchodzi do tyłu. Koncepcje te rozumiane są całkowicie na odwrót. Przyszłość jest usytuowana z tyłu, za określonym momentem trwania jednostki. Innymi słowy, oznacza to, że nadchodzi z tyłu, jest zależna od tego, co było i jest. Przeszłość jest usytuowana z przodu, a więc odchodzi w dal, znajduje się zawsze po czymś, wyprzedza i warunkuje to, co ma się wydarzyć.

${ }^{15}$ Na przykład w wiosce Mojandita (prowincja Imbabura) istnieje przekonanie, że nie można wchodzić do pobliskiego lasu po zmroku, czyli godzinie 18.00 (odniesienie jednocześnie do czasu i przestrzeni). Mieszkańcy tłumaczą, że złamanie tej normy zakłóciłoby pracę roślin, które w tym czasie rozmnażają się, jedzą i pracują. Złamanie tej normy przez człowieka ma swoje konsekwencje - np. powoduje chorobę. 
ze sobą elementach tego, co się wydarzyło, tego, co jest i co dopiero nadejdzie. Człowiek nie rodzi się jako biała karta, która dopiero w procesie socjalizacji zdobywa kompetencje kulturowe. Wiedza jest transmitowana poprzez codzienne działanie w wyniku przekazu i obserwacji członków rodziny i wspólnoty. Przekazywana także po ich śmierci, gdyż zmarli mogą nawiązywać sprawcze relacje z żywymi. Życie doczesne jest więc konsekwencją i kumulacją tego, jak żyli przodkowie. Dlatego też Kiczua twierdzą, że przyszłość jest z tyłu, nie z przodu.

\section{Mitopraktyka szamanów Kiczua}

Zgodnie ze współczesnymi narracjami yachak czas świata dzieli się na trzy epoki - dawna epoka, epoka podboju i nowa epoka. Każda z nich liczy 500 lat. Pierwsza epoka wyznacza czas przed podbojem obu Ameryk przez Hiszpanów i symbolizuje okres harmonii oraz porządku. Epoka podboju to okres kolonizacji, który jest dla Kiczua czasem chaosu, cierpienia oraz strachu. Nowa epoka to z kolei czas powrotu harmonii. Według yachak przybycie Hiszpanów zostało przewidziane przez proroków i szamanów (przepowiednie na podstawie snów, wizji i wyroczni) już w czasach inkaskich. Według yachak Inkowie spodziewali się nastania "czasów ciemnych" oznaczających koniec ich kultury i cywilizacji oraz nastanie innego porządku. Proroctwa inkaskie opisywali np. Inca Garcilaso de la Vega (2013: 352-354) oraz Felipe Guaman Poma de Ayala (1936: 179-180). Zgodnie $\mathrm{z}$ ich narracjami pojawienie się Białych poprzedzały niezwykłe wydarzenia - silne trzęsienia ziemi, wzburzenie oceanu, ruch ciał niebieskich (komety) oraz nadzwyczajne zjawiska atmosferyczne (błyskawice czy zaćmienia księżyca). Przepowiednie inkaskich kapłanów (podczas panowania ósmego Inki) mówią o śmierci ostatniego (dwunastego) Inki, wielkiej wojnie i zniszczeniu imperium Tawantinsuyu. Współczesna mitopraktyka yachak wnosi kilka nowych elementów, które w kronikach nie występują. Opowiadają oni bowiem, iż inkascy kapłani (szamani) na początku konkwisty hiszpańskiej przetransformowali się w inne byty (np. szczyty górskie, wulkany) lub w „zwykłych” ludzi. Wiedzieli, że nie zdołają przeciwdziałać tragicznym wydarzeniom. Ówcześni szamani „uśpili" swoje moce i wiedzę przekazywaną z pokolenia na pokolenie. W ten sposób dziedzictwo ich przodków miało przetrwać 500 lat kolonializmu. Wraz z nastaniem kolejnej epoki, datowanej przez yachak na ok. 2000 r., rozpoczęło się wielkie przebudzenie yachak oraz ich wiedzy nazywane w kiczua pachakutik.

Koncepcja pachakutik łączy pojęcia pacha (kicz. czas i przestrzeń) oraz cutig (kicz. zmiana, powrót) - dosłownie "ten, co transformuje", "ten, co powraca”. Pachakutik jest więc transformacją czasu i przestrzeni ${ }^{16}$. Przypomnę, iż termin pa-

\footnotetext{
${ }^{16}$ Współcześnie, oprócz wymiaru społecznego (kolektywnego), koncepcja pachakutik urzeczywistnia się także $\mathrm{w}$ wymiarze indywidualnym. Transformacji może ulec życie człowieka pod wpływem działania bytów nie-ludzkich (np. apus - góry, które są opiekunami danej
} 
cha narzuca rozumienie transformacji czy zmiany poprzez zatoczenie koła, czyli powrót. Inkaski mit pachakutik w wyniku współczesnych przemian także uległ redefinicji. Interpretowany jest przez yachak na dwa sposoby. Może być rozumiany jako powrót wiedzy, wartości, sposobów życia i zwyczajów indiańskich. Interpretacja ta charakterystyczna jest dla tych yachak, którzy mimo dostępu do cywilizacji (mieszkają blisko miasta) starają się żyć w "tradycyjny" sposób:

Dla mnie pachakutik to powrót naszej duchowości, wiedzy, naszego rozumienia świata. To się właśnie dzieje. Wyobraź sobie 500 lat kłamstw, silnych ciosów, teraz właśnie jesteśmy na drodze do odzyskania tego, co utraciliśmy. Popatrz na medycynę andyjską, jest kontynuowana, odbudowujemy naszą wiedzę o leczeniu, o rytuałach. Wierzę w to, dzięki mężczyznom i kobietom, którzy posiadają wielką wiedzę i dzięki nim będziemy to kontynuować. [...] Pachakutik zrealizuje się, kiedy Indianie się zmienią, poprawią. Kiedy to się naprawi, wtedy naprawdę wyjdziemy z czasów ciemności. Żeby świat się zmienił musi się zmienić nasze działanie. Człowiek z Andów zawsze był realistą, mówić zawsze oznacza robić.

Yachak z Bashacan (prowincja Chimborazo)

Powrót wiedzy to zmiana sposobu życia Indian. Wiedza i działanie nigdy nie są od siebie rozdzielone. Aby mit o pachakutik się wypełnił, ludzie muszą działać zgodnie z jego treścią. Dlatego też dla yachak ważne jest podtrzymywanie, praktykowanie oraz transmitowanie tego, jak rozumieją „bycie człowiekiem”.

Okres, który nastał po 2000 r., yachak nazywają levantamiento de yachak; retorno de yachak oraz despertamietno de yachak (powstanie yachak; powrót yachak; przebudzenie yachak). W tym właśnie czasie rozpoczął się szereg transformacji politycznych - „odrodzenie indiańskie”, w którym yachak brali aktywny udział. Pachakutik to mit o charakterze utopijnym opartym na kiczuańskiej strukturze czasowo-przestrzennej, która legitymizuje opór przeciwko dominacji hiszpańskiej $^{17}$, a współcześnie opór przeciwko dominacji metyskiej ${ }^{18}$. Antykolonialne

wspólnoty) mogących wymierzać sprawiedliwość - ukarać za złe postępowanie, pozbawiając dobytku i zdrowia, lub nagrodzić za dobre postępowanie i życie w zgodzie z zasadą ayni (wzajemność), zsyłając urodzaj lub multiplikując zwierzęta. Indywidualny wymiar pachakutik związany jest także z koncepcją śmierci i życia po śmierci. Pod wpływem religii katolickiej niektóre grupy Kiczua wierzą, że po śmierci dusza człowieka zamienia się w gołębia i odlatuje do selvy (yunka) lub do nieba (janan pacha). To, co dzieje się z duszą po śmierci, uzależnione jest od życia, jakie człowiek wiódł na ziemi (kay pacha). Jeśli był biedny i mimo to postępował zgodnie z normami, po śmierci jego dusza dozna dostatku i spokoju. Jeśli człowiek był bogaty, ale postępował niegodnie, wówczas po śmierci będzie cierpiał głód i zimno.

${ }_{17}$ Całkiem inny stosunek do historii związanej z Inkami mają np. Cañaris (grupa Kiczua zamieszkująca prowincję Cañar), którzy wyraźnie odcinają się od teorii trakujących Inków jako swoich przodków. Inna wizja historii związana jest z pamięcią o krwawych walkach tej grupy z Inkami. Cañari stworzyli w poł. XV w. najważniejszą federację, ale Inkowie ostatecznie zmusili ich do posłuszeństwa. Niemniej jednak autoprezentują się jako jedyni, którzy zdołali oprzeć się władzy inkaskiej.

${ }^{18}$ Oprócz interpretacji szamanów i sposobów jej dalszej konceptualizacji koncepcja Pachakutik została wykorzystana przez powstałą w 1995 r. partię Movimiento de Unidad Plurinacio- 
ruchy oporu obecne były od początku okresu dominacji hiszpańskiej (Ramón Valarezo 1987), przybierały one różne formy i ożywały z różnym nasileniem. Urzeczywistniały się jako zbrojne bunty, które trwały do początków XX w. (Moreno Yánez 1985, 1994) w postaci wcześniej wspomnianej agresji szamanów opisanej przez Franka Salomona (1983) oraz ruchów natywistycznych i mesjanistycznych (Klumpp 1984). Mitopraktyka yachak została po raz pierwszy zaobserwowana przeze mnie w $2010 \mathrm{r}$. Z relacji tamtejszych yachak wynika, iż jest ona wtórna, tj. nie była przekazywana z pokolenia na pokolenie. Część yachak mówi o tym, że nowe elementy zostały inkorporowane od szamanów z Peru lub bezpośrednio z przepowiedni inkaskich, inni zaś wspominają o roli „przebudzonych" yachak $\mathrm{w}$ jego transmisji. Jednak $\mathrm{z}$ ich relacji wynika jednoznacznie, że pojawienie się tych mitów w narracjach yachak datowane jest na lata $90 . \mathrm{XX}$ w. Nie jestem w stanie ocenić genezy i procesu transformacji motywów mitologicznych na obszarze Ekwadoru, lecz nie to jest przedmiotem mojej analizy. Interesuje mnie głównie mechanizm i cel reinterpretacji mitów w praktykach yachak.

Krótki rzut oka na peruwiańskie wersje mitów bogatych w podobne motywy pozwoli nam na rozszerzenie kontekstu. Peruwiańscy etnografowie w połowie lat 50. XX w. zebrali kilkanaście wersji mitu opisującego motyw „powrotu starego porządku"19. Centralnym motywem tych opowieści była postać Inkarrí - mitycznego bohatera o nadprzyrodzonych mocach, który utożsamiany jest z Inką lub pra-człowiekiem, od którego (ze związku z boginią Qollarí) pochodzą pierwsi ludzie (runakuna). Zdaniem badaczy Inkarrí jest symbolem reprezentującym historię i kulturę tubylczą w czasach konkwisty (Ossio 2000: 182). Jak głosi mit, Inkarrí został pojmany przez Hiszpanów i zabity na skutek dekapitacji (w innych wersjach poćwiartowany). Zgodnie z opowieściami peruwiańscy Keczua oczekują odtworzenia ciała Inkarrí przez odrośnięcie głowy (lub zrośnięcie się ciała), co doprowadzić ma do odtworzenia porządku inkaskiego. Ciało Inkarrí staje się więc ciałem społecznym. Inne peruwiańskie wersje mówią o powrocie lub narodzinach nowego Inki, który odmieni los Indian i przywróci porządek sprzed konkwisty ${ }^{20}$. Symptomatyczny jest fakt, że w Peru wciąż oczekuje się powrotu inkaskiego przywódcy. Istotna jest tu, jak sądzę, sytuacja polityczna Indian, która w Ekwadorze jest znacznie bardziej korzystna. Wersja ekwadorska depersonalizuje mit o powrocie i jest moim zdaniem swoistym nawiązaniem do obecnej sytuacji społeczno-politycznej. Odzwierciedlają to narracje yachak.

nal Pachakutik (MUPP), o charakterze indygenistycznym oraz antykapitalistycznym, której główny program opiera się na ideach poszanowania różnorodności, interkulturowości. Więcej o powstaniu organizacji i nawiązaniu do mitu Pachakutik piszą S.H. Beck i K.J. Mijeski (2011) oraz N.E. Whitten (2003).

${ }^{19}$ Różne warianty mitu o Inkarrí zostały zebrane w następujących regionach Peru: Puquio (Lucanas-Ayacucho), Andamarca (Lucanas-Ayacucho), Quinua (Huamanga-Ayacucho), Saurama (Ayacucho), Q'eros (Paucartambo-Cuzco), San Pablo (Canchis-Cusco), Qollana-Wasak (Paucartambo-Cusco), Lauramarca (Cusco), Llallapara (Cusco), Poqes (Calca-Cusco), Cheqa Pupuja (Azángaro-Puno), Vicos (Ancash), Lima (Barriada), Fuerrabamba (Apurímac), Valle del Colca (Caylloma-Arequipa) i u Asháninka (Amazonia de Junín) (Ossio 1973).

${ }^{20}$ Więcej o peruwiańskiej wersji mitu np. T. i H. Müller (1984) oraz S.M. Steckbauer (1998). 
Ekwadorscy szamani podkreślają wyraźnie fakt, iż proces powrotu trwa, rozpoczął się wraz z nowym milenium, czego symptomem są aktualne przemiany społeczno-polityczne. Moje rozmowy z peruwiańskimi szamanami pokazują zaś, że wciąż oczekują oni na zwrotny moment w swojej historii i że proces ten jeszcze się nie rozpoczął.

Kolejny mit, któremu się przyjrzymy, to opowieść o kondorze i orle. Według narracji yachak kondor symbolizuje świat indiański, orzeł zaś świat nie-indiański („zachodni”). Epoka dawna (przed inwazją Europejczyków) była czasem, kiedy cała ludzkość stanowiła jedną grupę. Nadszedł jednak moment, w którym ich drogi rozeszły się - nastąpiło rozdzielenie ludzkości na dwie części. Jedna grupa (symbol orła) wyruszyła na północ - byli to „ludzie umysłu”, którzy rozwijali naukę i technologię. Druga grupa (symbol kondora) wyruszyła na południe. Byli to "ludzie serca" - rozwijali duchowe umiejętności oraz relacje ze światem natury. Według yachak nowa epoka, po wypełnieniu się przepowiedni pachakutik, niesie ze sobą czas mastay, czyli ponowne spotkanie niegdyś podzielonej ludzkości. Odtąd, jak twierdzą yachak, „,orzeł i kondor znów będą mogły latać razem”. Ponowne połączenie ma oznaczać czas harmonii, braterstwa i współpracy.

Wśród ekwadorskich yachak spotkałam się z dwiema interpretacjami tego mitu. Pierwsza wskazywała, iż spotkanie orła z kondorem nie jest tożsame z powrotem do stanu sprzed rozdzielenia się grup. Według tej interpretacji świat indiański i nie-indiański widziane są jako dwie odrębne części. Mimo iż mają one egzystować w harmonii, szacunku i równości, nie będą mogły wrócić do pierwotnego stanu i zjednoczyć się, tworząc jedną ludzkość. Drugi wariant interpretacji tego mitu mówi o połączeniu dwóch światów - indiańskiego i nie-indiańskiego. Zdaniem tych yachak transformacja ma objąć nie tylko Indian, ale wszystkich ludzi. W tym kontekście mit o kondorze i orle jest więc rozumiany jako ponowne połączenie niegdyś podzielonej ludzkości. Obie interpretacje yachak niosą przesłanie, że już niedługo nadejdzie czas, w którym wiedza indiańska nie tylko będzie respektowana, ale uzyska pozycję dominującą, a Biali oraz Metysi przejmą indiańskie sposoby życia, myślenia, wchodzenia w relacje z drugim człowiekiem oraz z przyrodą. Ponadto druga interpretacja mitu o kondorze i orle, obok idei wiedzy i wartości, włącza w swój obręb idee polityczne. Uważam, że reinterpretacja ta również wynika z przemian społeczno-politycznych, w których yachak brali aktywny udział (walka o podmiotowość polityczną). Dla nich idea "spotkania kondora i orła” oraz pachakutik jest całkowitym przewartościowaniem i odwróceniem dotychczasowego porządku - odwróceniem struktury. Yachak uważają, że po wypełnieniu się przepowiedni Indianie odzyskają władzę, a świat tubylczy - świat ",natury”, ,„światła”, ,"słońca” będzie górować nad zachodnim - światem "techniki i upadku".

Życiowe historie i doświadczenia yachak, z którymi rozmawiałam podczas badań, okazały się być bardzo podobne. Większość z nich pochodziła z ubogich rodzin wiejskich, które pracowały najczęściej w encomiendas bez prawa jej opuszczenia, kilka dni w tygodniu. Takie warunki wiązały się $\mathrm{z}$ brakiem czasu na pracę na własnych poletkach, a w konsekwencji przyczyniały się do głodu 
lub niedostatku. Dzieci, które musiały pracować razem z rodzicami, nie były posyłane do szkół. Lepsza sytuacja dotyczyła Indian w miastach, ale przez długi czas (właściwie do połowy XX w.) tylko chłopcy odbierali podstawową edukację. Yachak pomimo wielu trudności związanych z brakiem pieniędzy i ze słabym dostępem do edukacji uzyskali wykształcenie podstawowe (często niepełne), a w późniejszym czasie nieliczni z nich także wykształcenie zawodowe, techniczne, rzadko wyższe. Zdobycie edukacji, nowe doświadczenia, w tym przede wszystkim poznanie mechanizmów funkcjonowania świata metyskiego, pociągnęło za sobą także zmiany mentalne. Edukacja i stopniowe wkraczanie do społeczeństwa metyskiego wpłynęło również na konkretne działania szamanów - tzw. pracę u podstaw. Ci yachak, którzy zdobyli elementarną wiedzę szkolną (nauczyli się czytać i pisać), rozpoczęli nauczanie w swoich rodzimych wioskach. Organizowano lekcje oraz warsztaty dla lokalnej społeczności z zakresu podstaw pisania i czytania, nauki muzyki oraz organizowano wydarzenia sportowe ${ }^{21}$. Większość yachak, oprócz aktywności oddolnych, bardzo szybko włączyła się do działalności politycznej na szczeblu ponadregionalnym (narodowym). Dołączali lub sami tworzyli nowe organizacje i stowarzyszenia indiańskie. W ten sposób włączyli się w nurt wspomnianego aktywizmu tubylczego i walczyli o te same prawa oraz przywileje, które wypracowywali inni politycy indiańscy. Szczególną uwagę zwracali na kwestie kulturowe. Szamani walczyli przede wszystkim o prawa do podtrzymywania własnych zwyczajów, wierzeń i rytuałów oraz prawo do praktykowania tradycyjnych metod leczenia. Yachak opowiadają o swojej pracy w comunidades:

Potem jak skończyliśmy trzy klasy, ja z moimi braćmi, zaczęliśmy uczyć czytać i pisać dzieci z naszej wsi. Oprócz tego, mówiliśmy im, że jesteśmy tacy jak wszyscy, że nie powinni nas poniżać, traktować jak zwierzęta, ignorantów, którzy nadają się tylko do pracy.

Yachak z wioski Bashacan (prowincja Chimborazo)

Gdy skończyłam szkołę, zaczęłam uczyć o ziołach, o leczeniu, zaczęłam organizować przemówienia i warsztaty dla mojej społeczności i innych wiosek. Tak pracowałam 3 lata. Starałam się zachęcać Indian, organizować ich. Wszystko przez moje doświadczenia, przez to jak traktowali mnie i moich rodziców. Musiałam się temu przeciwstawić. W końcu ludzie zaczęli się jednoczyć i zaczęliśmy mówić, że tak nie powinno być, zaczęły się protesty, marsze, mówiliśmy, że my też mamy wiedzę, mamy możliwości, jesteśmy inteligentni, że potrafimy produkować, że jesteśmy ludźmi, którzy produkują żywność dla całego kraju. Ziemniaki, kukurydza, dlaczego więc nas tak poniżali, wykorzystywali? Zaczęliśmy organizować się na poziomie państwowym, zjednoczyliśmy siłę Indian z różnych części kraju. Tak stopniowo zaczęliśmy tworzyć różne indiańskie organizacje, to, co dzisiaj nazywa się CONAIE.

Yachak z wioski Mojandita (prowincja Imbabura)

${ }^{21}$ Działania te, jak twierdzą szamani, miały na celu aktywizację Indian, zacieśnienie więzi pomiędzy członkami wspólnoty oraz nabranie większej wiary w siebie i swoje możliwości. 
Yachak jako aktywni działacze społeczni na szczeblu lokalnym, zaangażowani w codzienne życie swych wspólnot, w naturalny sposób wpisali się w rodzącą się politykę etniczną oraz ją współtworzyli. Zaczęli rozpowszechniać i rewaloryzować własną wiedzą, tworzyć elementy nowej tożsamości oraz rekonstruować treści kulturowe. Sami yachak uważają, że stanowili trzon ruchu indiańskiego, niektórzy twierdzą też, że go zainicjowali:

Przez długi czas byłem przywódcą organizacji indiańskich na poziomie prowincjonalnym i comunidades [wiosek]. Odkąd skończyłem 15 lat zacząłem się tym zajmować. Pracowałem z dziećmi, młodzieżą, zajmowałem się kulturą, edukacją, sportem, różnymi aktywnościami. [...] Ja i inni yachak, pracowaliśmy z ludźmi ze wsi, walczyliśmy o różne rzeczy. O ziemię, edukację, prawa do leczenia według naszych zwyczajów, o naszą kulturę, korzenie, o prawa dla Indian. Udało nam się wywalczyć dużo rzeczy, i wewnątrz tego było właśnie dużo yachak.

Yachak z Calpi (prowincja Chimborazo)

Generujemy wielkie ruchy. Tam gdzie są transformacje zawsze jest yachak. Człowiek szuka, szuka i znajduje yachak, który produkuje wiedzę. Ja nie robię nic wielkiego, przemawiam tylko do ludzi, którzy do mnie przychodzą, mówię im to, co muszą wiedzieć. Yachak zawsze zasiewa ziarno w wielkich rewolucjach, początkach wielkich zmian.

Yachak z Otavalo (prowincja Imbabura)

Po ustabilizowaniu się sytuacji politycznej część yachak opuściła rodzinne wioski, by prowadzić własne "gabinety" w miastach. Ich działania wciąż zmierzały w kierunku rewaloryzacji kultury indiańskiej. Wśród Indian i nie-Indian z nastawieniem proindiańskim zaczęli opowiadać nową historię - wizję nowych czasów i przyjścia nowej epoki. Proroctwa, do których odnoszą się yachak, są reinterpretacjami mitów inkaskich lub tych powstałych już w czasie kolonialnym. Współcześnie większość Kiczua widzi siebie jako ich bezpośrednich spadkobierców. Moim zdaniem jest to skutek polityki tożsamościowej prowadzonej przez yachak, opartej na tubylczych mitohistoriach. Przybiera ona charakter oddolny i lokalny. Nowe idee transmitowane są bowiem w naturalny sposób podczas codziennych spotkań, leczenia, porad, świąt i rytuałów. Yachak, którzy należą do pozarządowych lub rządowych organizacji, korzystają z narzędzi i możliwości świata metyskiego - organizują spotkania, konferencje, wykłady, szkolenia, warsztaty dla szamanów i uzdrawiaczy, wspólnot lokalnych, a także przedstawicieli społeczeństwa metyskiego (lekarzy, pielęgniarek, administracji lokalnej).

Trudno jest zatem, analizując te fakty, dotrzeć do początków wydarzeń, by ustalić ich kolejność. Można by snuć rozważania nad tym, czy najpierw (tak jak widzą to yachak) nastąpiło "przebudzenie”, czyli proces tworzenia się nowej historii, tożsamości, polityki, czy może owa aktywizacja i odrodzenie jest jedynie odpowiedzią, reakcją, swoistym narracyjnym komentarzem yachak do nowej sytuacji społeczno-politycznej ludności tubylczej? A może obie te odpowiedzi są możliwe? Pewne jest, że oba scenariusze schodzą się lub nakładają na siebie. 
Wydarzenia te działy się $\mathrm{w}$ tym samym czasie i dlatego tak trudno je wyodrębnić. Lecz czy, jak przekonują sami yachak, byli oni inicjatorami i przywódcami owego "odrodzenia indiańskiego"? Jak sami tłumaczą, nie mogli ujawniać swojej tożsamości, gdyż wiązałoby się to $\mathrm{z}$ ich dyskredytacją i prześladowaniami. $\mathrm{W}$ tym okresie yachak (i inni indiańscy uzdrowiciele) byli bowiem postrzegani jako kłamcy, oszuści, zabójcy lub „czarownicy mający pakt z diabłem”. Mimo iż nie jestem przekonana o tak znaczącej roli yachak $\mathrm{w}$ politycznych wydarzeniach, ich aktywny udział był faktyczny. Nie widzę jednak szczególnej konieczności rozstrzygania tego problemu na potrzeby niniejszego tekstu. Rozwiązanie tej zagadki nie pomoże nam bynajmniej w próbie spojrzenia na historię oczyma tubylca. Warto jednak zauważyć, że nawet jeśli te scenariusze wydarzeń są wyolbrzymione, ich postawa demonstruje duży spryt i umiejętność dostosowania się do sytuacji. $W$ przeciwieństwie do innych indiańskich działaczy politycznych yachak zawsze usytuowani byli blisko lokalnych wspólnot, żyjąc z nimi lub podtrzymując stały kontakt. Wspólnota jest bowiem fundamentem ich społecznego powodzenia i działania. Znając potrzeby Indian, yachak w błyskotliwy sposób włączyli się w nurt zachodzących przemian i zaczęli wypracowywać własne drogi działania, niezależne od indiańskich działaczy czy aktywistów.

Rozważmy następnie sposoby prowadzenia narracji historycznej przez yachak. Na podstawie analizy mitopraktyk wyodrębnić można kilka stałych mechanizmów jej konstruowania, które odsłaniają ich sposób myślenia o sobie (Indianach) i o nie-Indianach ${ }^{22}$. Nie ulega wątpliwości i nie jest również zaskoczeniem fakt, że opowieści generowane przez yachak są w dużej mierze spowite etnocentryzmem, esencjalizmem i demonizacją Innego (nie-Indianina). W konsekwencji wyodrębniłam cztery podstawowe kategorie: (1) opozycja (dychotomizacja), (2) negacja, (3) mityzacja przeszłości oraz (4) nowy język. Historia tworzona przez yachak w swej strukturze stoi w (1) opozycji do historii zachodniej. Świat lepszy (indiański) przeciwstawiany jest gorszemu (nie-indiańskiemu). Mechanizm ten opiera się na stosowaniu binarnych opozycji my/oni, dobry/ zły, ofiara/ciemiężyciel, prawda/kłamstwo. W konsekwencji kultura zachodnia ulega esencjalizacji. Jak doskonale wiemy, Indianie też mają swych Innych (o tym pisze więcej Clifford w tekście Kłopoty z kultura, patrz: 2000: 278). Jest to przykład waloryzacji swojej kulturowej odmienności i negacji kultury zachodniej jako opresyjnej.

Dychotomizacja tych światów opiera się na ich kontrastowaniu polegającym na jednoczesnym (2) zaprzeczeniu wartości kultury nie-indiańskiej i (3) mityzacji własnych wartości i przeszłości. Yachak wykazują zdecydowanie antyzachodnie nastawienie, deprecjonują zachodnią edukację, historię, wartości, sposób życia, który według nich nastawiony jest na konsumpcjonizm i zniewolenie. Zakulturowani Indianie, żyjący w miastach (cholos), przez część yachak z Chimborazo

${ }^{22}$ Celowo używam określenia nie-Indianin zamiast nie-Kiczua, dlatego że wizje głoszone przez yachak przesiąknięte są ideami panindiańskimi. Światopoglądy różnych grup indiańskich sprowadzane są tym samym do wspólnego mianownika. Uniwersalizują także kulturę metyską i euro-amerykańską, którą widzą jako opozycyjną i zagrażającą całość. 
nazywani są „, anty-Indianami”. Ich zdaniem to, co zachodnie, jest fałszywe, niepełne i uzurpujące sobie prawa do posiadania "kultury". Yachak z Otavalo (Imbabura), który w młodości rozpoczął edukację na uniwersytecie, ale ją porzucił, twierdzi, że w Europie nigdy nie było „kultury”. „Kultura” w jego rozumieniu sprowadza się do wielkich cywilizacji, takich jak Inkowie czy Aztekowie. Oto przykład jego wizji Europy i świata indiańskiego:

Są dwie drogi. Droga, którą wybrała Europa, to droga pamięci, analizy, logiki, rozumu. My [Indianie] wybraliśmy inną drogę, zbieramy i przekazujemy wiedzę, która istnieje w rzeczywistości. Wszystko jest wiedzą, wszystko co nas otacza. Yachak mają misję zasiewania wiedzy. My kontaktujemy się z Pachamama i wtedy wiemy wszystko. Europejczycy produkują wiedzę, która jest nieprzydatna, która zamiast generować harmonię i rozwój, przynosi głód, wojny i choroby. [...] Europie brakuje uczuć, jest zlodowaciała, nie ma serca. [...] Kiedyś w Europie też byli yachak, ale ich spalono. Księża, chrześcijanie, oni ich spalili. Tutaj też tak było. [...] Europejczycy nie mieli kultury [chodzi tu o tzw. wielkie cywilizacje]. Inkowie mieli kulturę, byli jej źródłem. Potem Indianie cierpieli 500 lat, dlatego teraz żyją jak niewolnicy. Płaci się im jak niewolnikom. Kultura zachodnia ma formę niewolniczą, a najlepsi niewolnicy są na uniwersytetach. Oni studiują, żeby być bardzo wytwornymi niewolnikami. Indianie przejęli tę formę od Europejczyków. [...] Indianie też mieli wojny, ale to było jak ojcowska kara, wtedy kiedy ojciec karze swoje dziecko. Oni nie chcieli zabijać, chcieli zdyscyplinować tych, którzy byli nieposłuszni, którzy źle czynili, chcieli ich zmotywować. Taka była intencja.

Mityzacja przejawia się w ruchach natywistycznych, tj. w procesie „powrotu do korzeni", i w przypadku praktyk szamanistycznych skorelowana jest z praktykami rytualnymi. Yachak głoszą powrót do poprzedniej formy życia i wchodzenia $\mathrm{w}$ relacje z naturą. Głoszą powrót do dawnych sposobów uprawiania ziemi (bez stosowania pestycydów, zgodnie z kalendarzem lunarnym), do dawnych form budownictwa (z naturalnych materiałów), sposobów zarobkowania, miejsca zamieszkania, diety (rodzaju i pochodzenia żywności). Yachak krytykują zmiany, które zaszły pod wpływem asymilacji ze społeczeństwem metyskim czy procesu porzucania praktyk i wartości indiańskich na rzecz miejskiego stylu życia.

(4) Praktyki i interpretacje wytwarzają nową dialektykę. Szamani uważają, że oprócz wartości i zachowań kultury zachodniej, które stale konstatują, sam język hiszpański jest „,odwrócony", , zepsuty" $i$,zdegenerowany" ${ }^{23}$. Tym procesom towarzyszy także wytwarzanie się nowego języka używanego przez szamanów. Mówią oni o nowych czasach, które mają nastać i które dzięki yachak powoli są

\footnotetext{
${ }^{23}$ Szaman z Calpi (Chimborazo) podawał za przykład słowo „pielęgniarka” w języku hiszpańskim enfermera - pochodzi od słów enfermar, enfermo (hiszp. chorować, chory). Jego zdaniem słowo to, poprzez swój źródłosłów, oznacza osobę, która szkodzi zdrowiu, pogarsza zdrowie. W odwrotności do języka kiczua, w którym pielęgniarka brzmi kawsaytaicuch i znaczy, , ta/ten, który rozgrzewa, ożywia, pobudza". Dla szamanów każde słowo niesie za sobą określone znaczenie, czyli moc, zdolność do konkretnego działania, postulatywność, która jest realizowana. Szaman komentuje: „Język hiszpański jest podstępny. Każde wypowiadane słowo niesie ze sobą problemy, złą energię. Każde słowo, każdy wydawany dźwięk to moc [poder]".
} 
urzeczywistniane. W narracjach używane są zwroty odnoszące się do: „przebudzenia", „oświecenia”, ,"wyjścia z mroku”, ,"nowej, złotej epoki”, ,"misji”.

Równie ważne i interesujące wydaje się pytanie dotyczące tego, w jakim celu yachak tak postępują i jakie to wywołuje konsekwencje. Mit Pachakutik służy:

A. legitymizacji rosnącej pozycji politycznej yachak oraz ich funkcji i roli społecznej we wspólnocie;

B. wzmacnianiu poczucia solidarności, przynależności, tożsamości wspólnoty Kiczua;

C. umocnieniu kiczuańskich wierzeń, systemów wartości i praktyk, wizji świata.

(A) W nowej wizji przyszłości yachak w zręczny sposób odnajdują dla siebie kluczowe miejsce oraz rolę przywódców i nauczycieli. Jest to forma legitymizacji (urzeczywistnienia) ich władzy oraz umacniania roli i funkcji w społecznościach indiańskich. Sami yachak widzą siebie jako głównych przywódców na drodze do odrodzenia kultury indiańskiej i dowód na urzeczywistnienie inkaskich proroctw. Pełnią bardzo ważną rolę w procesie transformacji, gdyż to oni mają być przewodnikami Indian - wskazywać kierunek i drogę rozwoju ${ }^{24}$.

Yachak jest jak promyk, który rozświetla ciemność. Jest jak drzewo pełne nasion, jesteśmy nasieniem tej ziemi. Ziarno z drzewa spada i z tego powstaje las, potem nikt już nie wie, z którego drzewa pochodziło. Ty słyszysz więc, że pieśń indiańska [kultura indiańska] odrodziła się i jest silna. To jest rola yachak. Sednem istnienia yachak jest bycie panem swojego przeznaczenia, odnalezienie drogi i przebudzenie tych, którzy żyją na ziemi.

Yachak z Otavalo (prowincja Imbabura)

(B) Ważnym elementem tożsamości i autoprezentacji danej grupy jest historia. Amerykańska historyczka Caroline Bynum (2001: 19) sugeruje, że jeśli zmiana jest zastąpieniem jednej całości przez inną lub jej wyodrębnieniem z drugiej, w której jest ukryta, to musimy być w stanie wyjaśnić, skąd wiemy, iż to od niej właśnie wychodzimy. Uważam, że powyższe reinterpretacje koncepcji $p a-$ chakutik są elementem procesu dekolonizacji, której podstawą było odrodzenie indiańskie. W konsekwencji zjawisko to powinno być interpretowane jako próba stworzenia nowej historii, nowej przestrzeni odbudowy i rozwoju kultury tubylczej. W końcu jest przykładem rodzenia się nowej tożsamości grup dotąd żyjących na marginesie społeczeństwa narodowego.

(C) Dwa powyższe skutki działania yachak generują zmiany w obrębie kultury Kiczua. Historia Kiczua to alternatywna interpretacja otaczającej nas rzeczywistości, umocowana na tubylczych koncepcjach zawartych głównie w mitach $\mathrm{i}$ opowieściach transmitowanych $\mathrm{z}$ pokolenia na pokolenie $\mathrm{w}$ formie ustnych

\footnotetext{
${ }^{24}$ Należy także zaznaczyć, że rewaloryzacja praktyk szamanistycznych wiąże się z budową podstawy ekonomicznej, nakręcaniem podaży związanej z praktyką medyczną. Jeśli Indianie będą chcieli uczestniczyć, organizować święta, rytuały, leczyć się u szamanów, szamani będą z tego czerpać więcej korzyści.
} 
przekazów. Oprócz funkcji światopoglądowej ludzie sięgają do mitów (mitohistorii) po to, by wzmocnić własne poglądy (wyobrażenia) i realizować własne interesy. Ich wybór (selekcja) zależy od tego, czy odpowiadają bieżącym interesom i wpasowują się w zastaną rzeczywistość. W czasie ich „wyciągania” i ponownego "wciągania” w przestrzeń dyskursu (idee i praktyki) ulegają przeobrażeniom, wykazując się przy tym dużą elastycznością i zdolnościami adaptacyjnymi (Buchowski 2010: 61). Nie oznacza to, że historia mityczna nie przekłada się na skuteczne działanie człowieka. Mit pachakutik może być rozumiany dosłownie i symbolicznie. Metafora zamienia się $\mathrm{w}$ fakt, mity są bowiem rzeczywistymi fikcjami. Nawet $\mathrm{w}$ naszym rozumieniu przekładają się na potoczny, codzienny ogląd rzeczywistości. Mity poprzez ich używanie czy działanie nimi stają się rzeczywiste. Clifford Geertz (2005a: 30) pisał, że fikcje są „fikcjami w tym sensie, że są »czymś skonstruowanym «, »czymś ukształtowanym « - takie jest bowiem pierwotne znaczenie słowa fictiō - nie chodzi tutaj o to, że są to rzeczy fałszywe, nieoparte na faktach, czy będące jedynie wydumanymi eksperymentami myślowymi".

W obu wizjach mitu koncepcja pachakutik nie jest konkretnym punktem w czasie, momentem zwrotu czy rewolucją (odwróceniem struktur), która odmienić ma bieg historii. Rozumiana jest raczej jako proces, który trwa w czasie, w którym każdy człowiek bierze udział i ma swoje zadanie do wykonania. Szamani podkreślają, że spełnienie się tego proroctwa wymaga dużo pracy - ich wkładu w transformację oraz pracę ze społecznościami indiańskimi. Obecną sytuację widzą zatem jako początek długiej drogi, która poprzez poprawę sytuacji prowadzić ma do powrotu równowagi i harmonii. Co 500 lat nastaje nowy etap, rozpoczyna się czas wielkich ruchów i transformacji społecznych, które prowadzą do powrotu wartości dotąd marginalizowanych. Koncepcja pachakutik jest też rozumiana jako siła napędowa transformacji, która otwiera nowy okres historyczny, ład społeczny.

Na koniec przeanalizujmy praktyczny aspekt mitopraktyki. Oprócz sfery narracji, koncepcja powrotu pojawia się także w praktykach rytualnych. Jak już nadmieniłam, jest ona zawarta w spiralnej czasowości Kiczua. Pachakutik jest tutaj rozumiany jako powrót do ñawpa pacha - dawnego czasu i przestrzeni. Wyobrażany w sferze wizualnej jako koło bądź spirala (porównywany do kędziora lub ślimaka), których forma stanowi podstawę do budowy ołtarza. Szamani wierzą, że fizyczne odtworzenie idei pachakutik (np. ołtarz) jest narzędziem do kontaktowania się z ożywionym światem natury oraz przodków, za pośrednictwem których uzyskują moc i wiedzę. Kiczua wierzą, że wiedza przekazywana jest także po śmierci. Nie może być tym samym zapomniana, gdyż funkcjonuje w obrębie odtwarzającej się spiralnej struktury trwania. Aspekt ten widoczny jest wyraźnie w kontekście koncepcji daru (hiszp. don), który jest podstawową własnością oraz wyznacznikiem wiedzy i praktyk szamanistycznych. Dar to wyjątkowa (posiadana przez wybrańców, tj. yachak), nadprzyrodzona (pochodząca od osób nie-ludzkich, tj. apus czy Pachamama) umiejętność, np. uzdrawiania, widzenia przeszłości i przyszłości czy kontaktowania się ze światem niewidzial- 
nym (innymi bytami osobowymi). Dar opisywany jest poprzez cechy osobowe. Po śmierci yachak don powraca i "wchodzi" w kolejnego potomka; dar "szuka tego, który godny jest go przyjąć". Według innych wyobrażeń to duch zmarłego yachak szuka odpowiedniej osoby, która mogłaby go przyjąć i wcielić (ang. embodiment). Dar jest zatem częścią historii każdej rodziny, linii czy generacji. Wraz ze śmiercią yachak powraca i jest przekazywany dalej z pokolenia na pokolenie.

\section{Zakończenie. Mitopraktyka jako tworzenie tożsamości}

Podobne procesy analizowane były przez takich badaczy jak np. Allan Hanson (1999), Eric Hobsbawm (2008) czy Richard Handler i Jocelyn Linnekin (1984). Ich prace pokazują, iż proces tworzenia kultury („wynalazek”) konstruowany poprzez zapożyczenia i ich reinterpretacje jest wysiłkiem zmierzającym do odbudowywania własnej kultury. Swojskość rozumiana jest przez Kiczua poprzez dwa aspekty - użyteczność oraz podobieństwo ${ }^{25}$. W kontekście mitopraktyki użyteczność pozwala na wytwarzanie własnej kultury, a podobieństwo na proces jej uautentycznienia. Reinterpretacje omówionych mitów wpisują się bowiem w koncepcję czasowości i rozumienie historii - głębokie struktury mentalne wspólne dla całego obszaru andyjskiego.

W przypadku społeczności postkolonialnych, złożonych z grup zdominowanych i dominujących, historia, jako kulturowo uwarunkowana struktura narracyjna, często staje się także narzędziem politycznym i poprzez jej redefinicje wykorzystywana jest do budowy nowej tożsamości. W andyjskim kontekście natywistyczne działania z czasem mogą stać się szansą na zrozumienie trudnej przeszłości. Dają możliwość pogodzenia się z latami ucisku, a także niesprawiedliwości ze strony najeźdźców oraz oswojenia się i zaakceptowania współczesnej pozycji i roli Indian w społeczeństwie Ekwadoru. Konstruowana przez yachak historia jawi się jako nadzieja na lepszą przyszłość i poprawę sytuacji Indian. Yachak, dzięki swojemu interkulturowemu usytuowaniu, stają się tłumaczami czy też agentami kontaktu, których zadaniem jest międzykulturowa translacja. Jednakże, już w punkcie wyjściowym analizy, pozycja ta staje się problematyczna. Etymologia słowa "translacja” (inaczej: przekład, metafraza) pochodzi od słowa translatio (łac. przeniesienie). Translacja czyniona przez yachak jest kulturowym transferem treści bazującym na pozytywnych (waloryzujących i akceptujących) lub negatywnych (zaprzeczających i wykluczających) przeobrażeniach. $W$ tym sensie proces transpozycji staje się aktem kreacji. Dotychczasowe, znane elementy zamieniają się $\mathrm{w}$ coś nowego, lecz czy tylko pozornie "tradycyjnego"? Robert J.C. Young (2012: 160) pisze (w kontekście

${ }^{25}$ Oprócz opsianych mitów szamani interpretują w podobny sposób treści o nieandyjskim charakterze. Na przykład historię Jezusa Chrystusa (jako szamana), tarot andyjski, taoizm. Nieco więcej na ten temat w artykule Szamani a szkota. Przeobrażenia modelu szkoty państwowej w kontekście kosmowizji wspótczesnych Indian Kiczua (w druku, Przytomska 2014b). 
analizy postkolonialności), że przemiana wynikająca z przekładu międzykulturowego zachodzi w sensie dosłownym, gdyż dotyczy rekonstrukcji "materialnej tożsamości" danej kultury. Zmiana taka zachodzi w przypadku historii Indian dwukrotnie. Kultura indiańska za pomocą mechanizmów kolonialnego reżimu została przeobrażona $\mathrm{w}$ kulturę poddańczą. W wyniku programu asymilacyjnego została ona siłą przesiana przez kolonialny aparat pojęciowy. Nie oznacza to jednak zrównania czy destrukcji, lecz rekonstrukcję, która „działa jako proces tłumaczeniowej dematerializacji”. Drugim punktem rekonstrukcji jest "odrodzenie indiańskie" i dalsze transformacje, które za sobą pociągnęło. Podsumowując, historia yachak to jednocześnie historia zmian ludności tubylczej wywołanych czynnikami wewnętrznymi i zewnętrznymi - aktywnościami zainicjowanymi przez samych Indian oraz wpływem świata nie-indiańskiego. $\mathrm{W}$ procesie międzykulturowych interakcji trudno jest oddzielić oba te bodźce. Zaciera się bowiem granica pomiędzy tym, co rodzime i obce, a przemiany, które nastąpiły, nie są wyraźne i czytelne. W procesie akulturacji oba kulturowe substraty nachodzą na siebie, transformują się lub scalają, tworząc nowe figury kulturowe. Koncepcja pachakutik jawi się jako próba zachowania czy odtworzenia ciągłości kulturowej, rekonstrukcji postkolonialnej tożsamości oraz chęć nawiązania sprawczych i świadomych relacji ze społeczeństwem nie-indiańskim.

W procesie wytwarzania władzy poprzez akty oporu dużą rolę odgrywali ci krajowcy, którzy bezpośrednio kontaktowali się z kolonizatorem. Takimi międzykulturowymi tłumaczami byli także ci, którzy migrowali ze wsi do miast. Interetniczny dialog i zawarta $\mathrm{w}$ nim translacja stały się ich codziennym doświadczeniem. Young (2012: 163-165), zastanawiając się nad kwestią tego, jak możliwe jest ponowne reaktywowanie podmiotowości (transformacja przedmiotu w podmiot), przywołuje wydarzenie $\mathrm{z}$ listopada $1953 \mathrm{r}$. z udziałem Frantza Fanona ${ }^{26}$, który to wkroczył do szpitala psychiatrycznego w Blida-Joinville (Algieria) i wydał polecenie zdjęcia kaftanów bezpieczeństwa z 69 pacjentów krajowców. Fanon wyjaśnił wówczas, że oto właśnie skończył się czas kaftanów, łańcuchów, podziału na kolonizatorów i tubylców i od tej pory wszyscy będą tworzyć grupę równych względem siebie. Zdaniem Younga jest to najbardziej symboliczna scena w życiu Frantza Fanona, który był potomkiem czarnego niewolnika, psychiatrą, pisarzem oraz działaczem politycznym. Przywołane wydarzenie jest aktem przekładu oraz próbą ponownego upodmiotowienia mającego na celu transformację dotąd pasywnych i zdominowanych pacjentów w świadome i sprawcze podmioty.

Przywołana scena przypomina mi działania yachak, którzy za pomocą takich narzędzi jak historia, natywizm, ruchy indiańskie próbują przebudować umysły i światy tubylców. Narracje, które prowadzą, oparte są na zerwaniu dotychczasowych form translacji (detranslacja) oraz wprowadzaniu nowych zasad

\footnotetext{
${ }^{26}$ Frantz Fanon - potomek czarnego niewolnika, psychiatra, pisarz (Algieria zrzuca zastonę; Wyklęty lud ziemi) oraz działacz polityczny. Całe swoje dorosłe życie poświęcił m.in. walce antykolonialnej, procesom dekolonizacyjnym i psychopatologii kolonizacji.
} 
opartych na negacji, odwróceniu, wyparciu, oporze czy transformacji. Zgodnie z tą wizją "fałszywych" tubylców należy uczynić ponownie "prawdziwymi" krajowcami. „Antyindianie” mają zrehabilitować się i powrócić do tego, co niegdyś porzucili. Albo też niewolników należy uwolnić z kajdanów, a ciemiężycieli pozbawić narzędzi władzy. Reguły podporządkowania są te same. Yachak, w ten sam sposób, jak czynili to kolonizatorzy, negują i demonizują podstawy kultury metyskiej czy „zachodniej”, by niegdyś zdewaluowana kultura tubylcza mogła ulec rewaloryzacji. Nowa opowieść prowadzona przez yachak jest wynikiem redefinicji przeszłości i uprawomocnieniem nowych działań i wartości. Opowieść o ucisku i walce przeciwko niemu nie jest jednak całkowicie nowa. Aktywny opór Indian i dążenie do wyzwolenia było obecne od początku okresu kolonialnego. Sprzeciw wyrażany był w sferze kulturowej ekspresji (ruchy religijne, folklor), ale także $\mathrm{w}$ działaniach politycznych - buntach, powstaniach, lokalnych walkach. Lecz czy współczesne, alternatywne narracje Indian i postawy oporu przestały jedynie niepozornie majaczyć gdzieś na horyzoncie historii i stały się narracjami równorzędnymi i respektowanymi? Proces przebudowy wywołany przez yachak odbywa się w sposób oddolny, jak na razie na małą skalę, krok po kroku.

Pytanie o współczesność i przeszłość kiczuańskich yachak jest zarazem pytaniem o Indian w ogóle. Na całym świecie nowoczesność nabrała cech przeszłych, w których dawne tradycje odbijają się we współczesności. Podkreślić należy, że oddolne czy ponadlokalne projekty tożsamościowe i kulturowe społeczności tubylczych nie są tylko sztucznie wymyśloną formą, zwaną przez badaczy "tradycją wynalezioną", złożoną z przypadkowo dobranych elementów. Są one wynikiem świadomej deklaracji poczucia autonomii oraz autentyczności i przez taki właśnie pryzmat powinny być postrzegane. Nowe indiańskie metafory są przecież przedłużeniem starej rzeczywistości, a więc jej częścią. Stanowią także formę nowej retoryki, która, prawdopodobnie, zapowiada nowe doświadczenia oraz nowy sposób postrzegania świata i Innego. Historia opowiadana przez Indian pokazuje procesualność kultury, żywotność, zmienność i ruch. Ludzie nadają sens samym sobie i stwarzają własną kulturę. Nie zgadzają się na rzeczywistość (np. ucisk i wyzysk), obserwują siebie i swoich Innych, poprzez działanie tworzą własne światy, wchodzą w nie, stają się ich częścią (internalizują je) i wtedy właśnie zaczynają w nie wierzyć. Poprzez świadomość własnej kultury potrafią ją zmieniać. Próby odwrócenia sfolkloryzowanej rzeczywistości $\mathrm{i}^{27}$ podejmowane przez yachak oraz przeobrażenia jej we własny alternatywy świat spotykają się raczej (także wśród badaczy) z krytyką lub ironicznym uśmiechem. Mówi się o tym, że Indianie "czynią to w zły sposób” - sięgają do przeszłości, ale używane przez nich elementy wcale nie są elementami ich dziedzictwa. Świat Zachodu wciąż obserwuje Indian z góry, a produkty ich praktyk widzi jako twory nowe,

${ }^{27}$ Mam tutaj na myśli elementy kultury (folkloru), które w potocznym oglądzie kojarzą się nam z tubylczością/indiańskością i sprowadzają się do artesanías na indiańskich straganach czy kolorowych lokalnych świąt organizowanych przede wszystkim z myślą o turystach. 
wynalezione i eklektyczne, a przez to nieautentyczne. Choć w rzeczywistości są przecież jak najbardziej prawdziwe i pełnowartościowe ${ }^{28}$.

\section{Literatura}

Albert, B., Ramos, A.R. (org.). (2002). Pacificando o branco: cosmologias do contato no NorteAmazônico. São Paulo: UNESP.

Axel, B.K. (2002). From the Margins: Historical Anthropology and Its Futures. Durham: Duke University Press.

Beck, S.H., Mijeski, K.J. (2011). Pachakutik and the Rise and Decline of the Ecuadorian Indigenous Movement. Ohio: Ohio University Press.

Bhabha, H. (1994). The Location of Culture. London: Routledge.

Bruner, E.M. (2011). Etnografia jako narracja. Przeł. E. Klekot, A. Szurek. W: V.W. Turner, E.M. Bruner (red.), Antropologia doświadczenia (s. 150-168). Kraków: Wydawnictwo Uniwersytetu Jagiellońskiego.

Buchowski, M. (2010). Polskie dyskursy o krwi, ziemi i narodzie. W: M. Drozd-Piasecka, A. Posern-Zieliński (red.), Antropologia polityki i polityka w antropologii (s. 41-64). Warszawa: Komitet Nauk Etnologicznych PAN, IAE PAN.

Bynum, C.W. (2001). Metamorphosis and Identity. New York: Zone Books.

Clifford, J. (2000). Kłopoty z kultura: dwudziestowieczna etnografia, literatura i sztuka. Przeł. E. Dżurak, J. Iracka, E. Klekot, M. Krupa, Sł. Sikora, M. Sznajderman. Warszawa: Wydawnictwo KR.

Clifford, J., Marcus, G. (1986). Writing Culture: the Poetics and Politics of Ethnography. Berkeley: University of California Press.

Cordero, L. (2006). Diccionario Quichua-Castellano y Castellano-Quichua. Quito: Corporación Editora Nacional.

Coronado, J. (2009). The Andes Imagined: Indigenismo, Society, and Modernity. Pittsburgh: Univeristy of Pittsburgh Press.

Domańska, E. (2010). Historia antropologiczna. Mikrohistoria. W: N.Z. Davis, Powrót Martina Guerre'a (s. 195-234). Poznań: Zysk i S-ka.

Fausto, C., Heckenberger, M. (2007). Time and memory in indigenous Amazonia. Anthropological perspectives. Gainesville: University Press of Florida.

Galo, R.V. (1987). La resistencia andina. Cayambe, 1500-1800. Quito: Centro Andino de Acción Popular.

Gandhi, L. (2008). Teoria postkolonialna. Wprowadzenie krytyczne. Przeł. J. Serwański. Poznań: Wydawnictwo Poznańskie.

Geertz, C. (2005). Wiedza lokalna. Dalsze eseje z zakresu antropologii interpretatywnej. Przeł. D. Wolska. Kraków: Wydawnictwo Uniwersytetu Jagiellońskiego.

Gow, P. (2001). An Amazonian myth and its history. Oxford: Oxford University Press.

\footnotetext{
${ }^{28}$ Niemniej nie musimy się wcale doszukiwać wspólnej dla wszystkich wizji obserwowanej rzeczywistości. Teraźniejszość otwarta jest przecież na nieskończone interpretacje. Antropologia zaś, bardzo często, okazuje się poszukiwaniem spójności w celu odnalezienia sprzeczności. W tym kontekście nasuwają się więc stale powracające pytania: Jak mówić o Innych, nie tylko głosem brzuchomówcy, oraz jak i gdzie szukać alternatywnych rozwiązań? Jak pisze K. Hastrup (2008: 22), antropologia winna nadać tej deklaracji kontekst teoretyczny, a nie tylko sentymentalny charakter.
} 
Handler, R., Linnekin, J. (1984). Tradition, Genuine or Spurious. The Journal of American Folklore, 97(385), 273-290.

Hanson, A. (1999). Kreowanie Maorysa: wynalazek kultury i jego logika. Przeł. J. Schmidt. W: M. Buchowski (red.), Amerykańska antropologia postmodernistyczna (s. 183-201). Warszawa: Instytut Kultury.

Hastrup, K. (2008). Droga do antropologii. Między doświadczeniem a teoria. Przeł. E. Klekot. Kraków: Wydawnictwo Uniwersytetu Jagiellońskiego.

Hobsbawm, E. (2008). Wprowadzenie. Wynajdowanie tradycji. Przeł. M. Godyń, F. Godyń. W: E. Hobsbawm, T. Ranger (red.), Tradycja wynaleziona (s. 9-23). Kraków: Wydawnictwo Uniwersytetu Jagiellońskiego.

Klumpp, K. (1974). El retorno de Inga: una expresión ecuatoriana de la ideología mesiánica andina. Cuadernos de Historia y Arqueología, 24(41), 99-135.

Lévi-Strauss, C. (1969). Myśl nieoswojona. Przeł. A. Zajączkowski. Warszawa: PWN.

Lindstrom, L. (1982). Leftamap Kastom: The Political History of Tradition on Tanna, Vanuatu. Mankind, 13, 316-329.

Monachesi, M. (2008). Profecias Incas/Inca Prophecies: Asombro y sabiduría en tiempos de cambio. Buenos Aires: Kier.

Moreno Yánez, S.E. (1985). Sublevaciones indígenas en la Audiencia de Quito, desde comienzos del siglo XVIII hasta finales de la Colonia. Quito: EDIPUCE.

Moreno Yánez, S.E. (1994). La etnohistoria y el protagonismo de los pueblos colonizados: contribución en el Ecuador. Revista Ecuatoriana de la Historia, 5, 53-73.

Müller T. i H. (1984). Mito de Inkarri-Qollari (cuatro narraciones). Allpanchis, 23, 125-143.

Oberem, U. (1971). Los Quijos: Historia de la transculturación de un grupo indígena en el Oriente Ecuatoriano, 1538-1956. Madryt: Facultad de Filosofía y Letras de la Universidad de Madrid.

O'Connor, E. (2003). Etnohistoria e historia nacional en el Ecuador: peonazgo, cultura de hacienda y estado nacional. W: J. Fisher, D. Cahill (eds.), De la Etnohistoria a la Historia en Los Andes (s. 233-268). Quito: Abya-Yala.

Ossio Acuña, J.M. (1973). Ideología Mesiánica del Mundo Andino. Lima: Ignacio Pastor.

Ossio Acuña, J.M. (2000). Inkarrí y el mesianismo andino. W: F. Navarrete Linares, G. Olivier (coord.), El héroe entre el mito y la historia (s. 181-212). México: Centro Francés de Estudios Mexicanos y Centroamericanos.

Poma de Ayala, F.G. (1936). El primer nueva corónica y buen gobierno. Paryż: Instituto Etnográfico.

Posern-Zieliński, A. (1987). Folk history, W: Z. Staszczak (red.), Stownik etnologiczny. Terminy ogólne. Warszawa-Poznań: PWN.

Posern-Zieliński, A. (2005). Między indygenizmem a indianizmem. Andyjscy Indianie na drodze do etnorozwoju. Poznań: Wydawnictwo Naukowe UAM.

Przytomska, A. (2014a). Reproduction and aggression. Shamanistic practices of Quichua Indians in the Ecuadorian Andes. W: D. Niezgoda, M.J. Kozłowski, (red.), Imagined America. The Humanities Reflections about New World. Kraków: Wydawnictwo Alter (w druku).

Przytomska, A. (2014b) Szamani a szkoła. Przeobrażenia modelu szkoły państwowej w kontekście kosmowizji współczesnych Indian Kiczua. W: T. Buliński, M. Rakoczy (red.), Communicare: almanach antropologiczny. Szkota/pismo (t. V). Warszawa: Wydawnictwo Uniwersytetu Warszawskiego (w druku).

Sahlins, M. (1997). O ‘pessimismo sentimental' e a experiência etnográfica: por que a cultura não é um 'objeto' em via de extinção (parte I). Mana, 3(1), 41-74. 
Sahlins, M. (2003). Inne czasy, inne zwyczaje. Antropologia historii. Przeł. E. Dżurak. W: M. Kempny, E. Nowicka (red.), Badanie kultury. Elementy teorii antropologicznej (s. 117145). Warszawa: Wydawnictwo Naukowe PWN.

Sahlins, M. (2006). Wyspy historii. Przeł. I. Kołbon. Kraków: Wydawnictwo Uniwersytetu Jagiellońskiego.

Salomon, F. (1983). Shamanism and politics in the late-colonial Ecuador. American Ethnologist, 10, 413-428.

Salomon, F. (1999) Testimonies: The Making and Reading of Native South American Historical Source, Cambridge: Cambridge University Press.

Steckbauer, S.M. (1998). Versiones escritas de tradiciones orales: el mito del Inkarrí. W: H.-J. König (ed.), El indio como sujeto y objeto de la historia latinoamericana. Pasado y presente (s. 53-67). Frankfurt n. M.: Vervuert.

De la Vega, I.G. (2013). Comentarios Reales de los Incas. Lima: Vitruvian.

Wallace, A.F.C. (1956). Revitalization Movements. American Anthropologist, New Series, $58(2), 264-281$.

Webster, S. (1974). Factores de Posición Social en una Comunidad Nativa Quechua. Estudios Andinos, 11, 131-159.

Whitten, N.E. (1976). Sacha Runa: Ethnicity and Adaptation of Ecuadorian Jungle Quichua. Urbana: University of Illinois Press.

Whitten, N.E. (2003). Millennial Ecuador. Critical essays. Iowa: University of Iowa Press.

Young, R.J.C. (2012). Postkolonializm. Wprowadzenie. Przeł. M. Król. Kraków: Wydawnictwo Uniwersytetu Jagiellońskiego.

\section{SUMMARY}

\section{Indigenous history. Shamans and mythopractice}

The article discusses issues of reproducing history, that is, indigenous strategies and mechanisms of constructing historical narrative among the Quichua in the Ecuadorian Andes. The indigenous historical practices are based on Inca myths and local tales transmitted orally (mythopractice). The background for this practices is constituted by contemporary political and social transformations in Ecuador - indigenous movements, obtaining legal personhood, multicultural policy, all of which offer the indigenous groups new opportunities to redefine themselves. Quichua shamans are also involved in these processes, and their activities have bottom-up and local character. In this paper, the following questions are addressed: how Quichua shamans reproduce history, why they do it, and what mechanisms they use. The responses to these questions allow to disclose and analyse the bottom-up attempts of building an identity and indigenous subjectivity in the postcolonial context of South America. This process is presented against the historical background of colonial policy about indigenous shamans and their involvement in colonial policy. The phenomenon of mythopractice is also explained through fundamental elements of Quichua worldview related to local understanding of time and change. This paper is based on field research on shamanistic practices conducted among the Ecuadoran Quichua in 2010 and 2012.

Key words: Ecuador, Quichua, anthropology of history, folk history, shamanism 